\title{
THE DYNAMICS OF THE G PROTEIN-COUPLED NEUROPEPTIDE Y2 RECEPTOR IN MONO- UNSATURATED MEMBRANES INVESTIGATED BY SOLID-STATE NMR SPECTROSCOPY
}

\author{
Lars Thomas ${ }^{1}$, Julian Kahr ${ }^{1,2}$, Peter Schmidt ${ }^{1}$, Ulrike Krug ${ }^{1}$, Holger A. Scheidt ${ }^{1}$, \\ Daniel Huster ${ }^{1, *}$ \\ ${ }^{1}$ Institute of Medical Physics and Biophysics, University of Leipzig, Härtelstr. 16-18, D- \\ 04107 Leipzig, Germany, University of Applied Sciences, Dr.-Friedrichs-Ring 2A, D- \\ 08056 Zwickau, Germany
}

\begin{abstract}
In contrast to the static snapshots provided by protein crystallography, $\mathrm{G}$ protein-coupled receptors constitute a group of proteins with highly dynamic properties, which are required in the receptors' function as signaling molecule. Here, the human neuropeptide $\mathrm{Y} 2$ receptor was reconstituted into a model membrane composed of monounsaturated phospholipids and solid-state NMR was used to characterize its dynamics. Qualitative static ${ }^{15} \mathrm{~N}$ NMR spectra and quantitative determination of ${ }^{1} \mathrm{H}^{-13} \mathrm{C}$ order parameters through measurement of the ${ }^{1} \mathrm{H}^{13}{ }^{13} \mathrm{C}$ dipolar couplings of the $\mathrm{CH}, \mathrm{CH}_{2}$ and $\mathrm{CH}_{3}$ groups revealed axially symmetric motions of the whole molecule in the membrane and molecular fluctuations of varying amplitude from all molecular segments. The molecular order parameters $\left(S_{\text {backbone }}=0.59\right.$ $0.67, \mathrm{~S}_{\mathrm{CH} 2}=0.41-0.51$ and $\mathrm{S}_{\mathrm{CH} 3}=0.22$ ) obtained in directly polarized ${ }^{13} \mathrm{C}$ NMR experiments demonstrate that the $\mathrm{Y} 2$ receptor is highly mobile in the native-like membrane. Interestingly, according to these results the receptor was found to be slightly more rigid in the membranes formed by the monounsaturated phospholipids than by saturated phospholipids as investigated previously. This could be caused by an increased chain length of the monounsaturated lipids, which may result in a higher helical content of the receptor. Furthermore, the incorporation of cholesterol, phosphatidylethanolamine, or negatively charged phosphatidylserine into the membrane did not have a significant influence on the molecular mobility of the $\mathrm{Y} 2$ receptor.
\end{abstract}

\section{Keywords}

order parameter, membrane protein, MAS NMR, fluctuations, motional amplitude

Correspondence to: Daniel Huster, Institute of Medical Physics and Biophysics, Medical Department, University of Leipzig, Härtelstraße 16-18, 04107 Leipzig, Germany, daniel.huster@medizin.uni-leipzig.de,+49-(0)-341-97 15701 (phone) 


\section{Introduction}

Membrane proteins like their soluble counterparts are dynamic entities that are subject to numerous dynamic processes with varying motional amplitudes and correlation times (Chill and Naider 2011; Hong et al. 2012; Huster 2005; Palmer III et al. 1996). Typically, one distinguishes between equilibrium fluctuations and non-equilibrium effects (Columbus and Hubbell 2002; Henzler-Wildman and Kern 2007; Reichert et al. 2012). Non-equilibrium dynamics comprises switching between different conformational states of the molecule upon activation by a structural transition from the ground into an activated state and vice versa. Equilibrium dynamics involves local fluctuations in the backbone and the side chain (Columbus and Hubbell 2002; Reichert et al. 2012). Such motions can occur as local (i.e. segmental) fluctuations as well as correlated motions of entire secondary structure units. All dynamic processes of a protein are the result of the complex energy landscape on which the protein exists (Frauenfelder et al. 1991).

G protein-coupled receptors (GPCRs) are pharmacologically extremely interesting membrane proteins, which initiate signal transduction cascades from external stimuli into the cell (Venkatakrishnan et al. 2013). There are about 800 GPCRs found in the human genome, which all feature the same topology of seven transmembrane $\alpha$-helices (Kobilka 2013). Within the last decade, structure information on these molecules became available after a long period of unsuccessful crystallization trials and attempts to solve the structures of these molecules by NMR spectroscopy (Kobilka 2013; Palczewski et al. 2000; Park et al. 2012; Venkatakrishnan et al. 2013). The relatively slow progress in the structure determination of GPCRs has often been ascribed to the particularities of GPCRs, such as a loose structural arrangement of these heptahelical proteins and their specific dynamics (Venkatakrishnan et al. 2013). With the exception of bovine rhodopsin, which was crystallized in its native form (Palczewski et al. 2000), crystallization only succeeded after the receptor was immobilized by anti- or nanobody binding, by removal of intracellular loops (often combined with a fusion protein strategy), or by thermostabilization through point mutations (Steyaert and Kobilka 2011; Venkatakrishnan et al. 2013; Warne et al. 2008).

These considerations suggest that GPCRs are relatively dynamic molecules in their natural environment that undergo a rich variety of molecular motions, which is also inferred from the relatively high crystallographic B-factors (Ding et al. 2013; Hubbell et al. 2003). Correspondingly, GPCR crystal structures also often lack electron density for loop and tail segments, suggesting that these molecular structures are statically disordered or may undergo large amplitude motions. Site-specific EPR measurements on rhodopsin have provided direct quantitative information on GPCR mobility. These studies underlined in detail the highly dynamic nature of rhodopsin (Hubbell et al. 2003).

NMR spectroscopy represents a very powerful biophysical method to study protein dynamics (Ding et al. 2013; Goncalves et al. 2010; Palmer III et al. 1996). The timescale of motions covered by NMR methods ranges from tens of picoseconds to milliseconds and beyond (Reichert et al. 2012). For membrane proteins in a native lipid environment solidstate NMR is the method of choice (Yao et al. 2013), which allows a more direct investigation of their dynamics because of the absence of the overall tumbling of soluble proteins (Opella 1986). Static solid-state NMR powder spectra indicate protein dynamics by a reduced breadth and the occurrence of narrow lines indicates the presence of molecular 
motions with large amplitude. Furthermore, from motionally averaged dipolar or quadrupolar coupling strengths, a molecular order parameter can be determined that provides a measure for the motional amplitude of a respective segment (Palmer III et al. 1996).

Several recent studies directly addressed the dynamics of recombinant GPCRs reconstituted into lipid membranes. The CXCR1 receptor was pronounced relatively rigid only undergoing axially symmetric rotational diffusion in the membrane (Park et al. 2011). Large amplitude motions were only observed for about $10 \%$ of the residues localized in the $\mathrm{N}$ - and C-termini. In contrast, a recent study of the neuropeptide $\mathrm{Y} 2$ receptor suggested that this molecule shows extended dynamics in the membrane on a time scale up to microseconds, involving motions with amplitudes on the order of $50^{\circ}$ and more even in the protein backbone (Schmidt et al. 2014). In addition, complex landscapes of excited-state conformers have been detected for the $\beta_{2}$-adrenergic receptor using solution NMR techniques (Chung et al. 2012). Several inactive states and activation intermediates have been identified for this receptor and the addition of the ligand changed the relative populations of these states (Kim et al. 2013). Also, the conformational dynamics of the transmembrane core of the receptor was characterized, providing insights into the substantial conformational heterogeneity of agonist- and inverse-agonist-bound preparations (Nygaard et al. 2013).

In the current study, we have investigated the dynamics of the neuropeptide $\mathrm{Y} 2$ receptor (Cabrele and Beck-Sickinger 2000) reconstituted into physiological model membranes of monounsaturated phospholipids. The 1-palmitoyl-2-oleoyl-sn-glycero-3-phosphocholine (POPC) is a highly abundant zwitterionic lipid in biological membranes. Furthermore, mixed membranes containing either cholesterol, the negatively charged 1-palmitoyl-2-sn-glycero3-phospho-L-serine (POPS), or the lipid 1-palmitoyl-2-oleoyl-sn-glycero-3-phosphoethanolamine (POPE) featuring high negative intrinsic curvature complete our study. Overall, we found a remarkable mobility of the membrane embedded GPCR in all membrane systems investigated. Although the current resolution prevents site-specific dynamics measurements for the $\mathrm{Y} 2$ receptor, it is plausible that a complex energy landscape is the reason for the protein dynamics observed. This energy landscape renders the Y2 receptor highly mobile in the biologically relevant liquid-crystalline phase state of the membrane.

\section{Materials and Methods}

\section{Expression of the $Y 2$ receptor}

The human Y2 receptor was expressed as a cysteine deficient form, where all cysteines except the two in the conserved disulfide bridge were replaced by Ala or Ser (Witte et al. 2013). Expression as inclusion bodies in E. coli in defined mineral salt medium using a fedbatch-fermentation process and functional refolding has been described before (Berger et al. 2011; Schmidt et al. 2010). Uniform ${ }^{15} \mathrm{~N}$-labeling of the receptor was achieved by using ${ }^{15} \mathrm{NH}_{4} \mathrm{Cl}$ and ${ }^{15}\left(\mathrm{NH}_{4}\right)_{2} \mathrm{SO}_{4}$ (Cambridge Isotope Lab., USA) as the sole nitrogen source in the fermentation medium. For the expression of $\mathrm{U}-{ }^{13} \mathrm{C} /{ }^{15} \mathrm{~N}$-labeled receptor, $\mathrm{U}-{ }^{13} \mathrm{C} 6 \mathrm{D}$-glucose (Cambridge Isotope Lab., USA) was applied to the medium in the feed phase, starting $30 \mathrm{~min}$ prior to induction ( $30 \mathrm{~g} / \mathrm{l}$ in total). Expression time was limited to $3 \mathrm{~h}$ to save labeled glucose. Expression yields reached 22 and $18 \mathrm{mg} / \mathrm{I}$ medium for the $\mathrm{U}-{ }^{15} \mathrm{~N}$ and $\mathrm{U}-{ }^{13} \mathrm{C} /{ }^{15} \mathrm{~N}$ labeled receptors, respectively. Inclusion body preparation, solubilization of the receptor molecules in SDS and receptor purification were performed as described before (Schmidt et al. 2009). 


\section{NMR sample preparation}

Purified $\mathrm{Y} 2$ receptor, solubilized in $15 \mathrm{mM}$ SDS, $50 \mathrm{mM}$ sodium phosphate at $\mathrm{pH}$ 8, was diluted to $0.5 \mathrm{mg} / \mathrm{ml}$ and dialyzed against a buffer containing $2 \mathrm{mM} \mathrm{SDS}, 50 \mathrm{mM}$ sodium phosphate, $1 \mathrm{mM}$ EDTA, $0.1 \mathrm{mM}$ reduced glutathione $(\mathrm{GSH})$, and $0.05 \mathrm{mM}$ oxidized glutathione (GSSG) at $\mathrm{pH} 8.5$ for $48 \mathrm{~h}$ for the formation of the functional disulfide bridge (Rudolph and Lilie 1996). For reconstitution, lyophilized powders of POPC, POPC/cholesterol (molar ratio: 70/30), POPC/POPS (molar ratio: 80/20), or POPC/POPE/POPS/cholesterol (molar ratio (40/40/10/10) (all lipids from Avanti Polar Lipids, Alabaster, AL), were dissolved in chloroform. The chloroform was removed using a rotary evaporator and the dried lipid film was dispersed in $50 \mathrm{mM}$ sodium phosphate buffer at $\mathrm{pH} 8$ to reach a total concentration of $10 \mathrm{mg} / \mathrm{ml}$ lipid. The lipid dispersions were solubilized with a 6-fold molar excess of 1,2-diheptanoyl-sn-glycero-3-phosphocholine (DHPC-C7) (Avanti Polar Lipids, USA) and heated to $60^{\circ} \mathrm{C}$ for $30 \mathrm{~min}$ (Son et al. 2012). Then, the Y2 receptor was incubated with the detergent/lipid mix $\left(40^{\circ} \mathrm{C}\right)$ at molar ratio of $1 / 180 / 1080$ receptor/lipid/DHPC-C7, followed by three cycles of fast temperature changes between $40^{\circ} \mathrm{C}$ and $0^{\circ} \mathrm{C}(20 \mathrm{~min}$ each step) (De Angelis and Opella 2007). After the temperature cycles, $75 \mathrm{mg} / \mathrm{ml}$ BioBeadsSM2 (Bio-Rad Lab., Germany) were added twice to the solution to remove the detergent. The resulting cloudy receptor/lipid dispersion was ultra-centrifuged at $86,000 \times \mathrm{g}$ overnight. The final NMR sample contained $\sim 6 \mathrm{mg}$ Y2 receptor at a receptor to lipid molar ratio of $\sim 1 / 175$ and a water content of $\sim 70 \mathrm{wt} \%$. For the sample that was used to record directly polarized static ${ }^{15} \mathrm{~N}$ NMR spectra, about $20 \mathrm{mg}$ of ${ }^{15} \mathrm{~N}$ labeled $\mathrm{Y} 2$ receptor was prepared at the same mixing ratio.

\section{NMR experiments}

Standard static ${ }^{15} \mathrm{~N}$ CP NMR spectra with Hahn echo detection were acquired on a Bruker Avance I $750 \mathrm{MHz}$ NMR spectrometer using a double-channel probe with a $5 \mathrm{~mm}$ coil. Static ${ }^{15} \mathrm{~N}$ NMR spectra were recorded with $\mathrm{CP}$ contact times between $35 \mu \mathrm{s}$ and $8 \mathrm{~ms}$ or by direct excitation. Typical $90^{\circ}$ pulses of $4 \mu$ s for ${ }^{1} \mathrm{H}$ and $6 \mu \mathrm{s}$ for ${ }^{15} \mathrm{~N}$ were used. In the $\mathrm{CP}$ spectra, the relaxation delay was $2.5 \mathrm{~s}$, in directly polarized ${ }^{15} \mathrm{~N}$ NMR experiments, the relaxation delay was $10 \mathrm{~s}$. During signal detection heteronuclear TPPM decoupling (Bennett et al. 1995) was applied with a radio-frequency field strength of $\sim 62 \mathrm{kHz}$. Simulations of the static ${ }^{15} \mathrm{~N}$ NMR line shape were conducted in Mathcad. CP build up curves for the isotropic and anisotropic spectral components were fitted to $I(t)=I_{0}\left(1-T_{I S} / T_{1 \rho}\right)^{-1}\left[\exp \left(-t / T_{1 \rho}\right)-\exp \left(-t / T_{I S}\right)\right]$ (Kolodziejski and Klinowski 2002). $I_{0}$ is the initial intensity, $T_{1 \rho}$ the relaxation time constant in the rotating frame, and $1 / T_{\text {IS }}$ the $\mathrm{CP}$ rate constant.

All ${ }^{13} \mathrm{C}$ MAS NMR experiments were carried out on a Bruker Avance III 600 NMR spectrometer using a double-resonance MAS probe equipped with a $4 \mathrm{~mm}$ spinning module. Typical $90^{\circ}$ pulse lengths were $4 \mu \mathrm{s}$ for ${ }^{1} \mathrm{H}$ and ${ }^{13} \mathrm{C}$, and $5 \mu \mathrm{s}$ for ${ }^{15} \mathrm{~N}$. The ${ }^{1} \mathrm{H}$ radiofrequency field strength during heteronuclear decoupling using Spinal64 (De Paepe et al. 2003) was $\sim 65 \mathrm{kHz}$. The ${ }^{13} \mathrm{C} /{ }^{15} \mathrm{~N}$ chemical shifts were referenced using external standards (Morcombe and Zilm 2003). Standard CPMAS, directly excited ${ }^{13} \mathrm{C}$ MAS and INEPT experiments were carried out at a MAS frequency of $7 \mathrm{kHz}$. The relaxation delay in ${ }^{13} \mathrm{C}$ CPMAS and directly excited ${ }^{13} \mathrm{C}$ MAS experiments was 2.5 and $5 \mathrm{~s}$, respectively. The ${ }^{13} \mathrm{C}-{ }^{1} \mathrm{H}$ dipolar couplings strength was measured in DIPSHIFT experiments (Munowitz et al. 1981) at a MAS frequency of $5 \mathrm{kHz}$. Frequency-switched Lee-Goldburg (FSLG) sequence (Bielecki et al. 1989) was used for ${ }^{1} \mathrm{H}-{ }^{1} \mathrm{H}$ homonuclear decoupling. Either direct excitation or $\mathrm{CP}$ with 
varying contact times of $20 \mu \mathrm{s}, 700 \mu \mathrm{s}$, or $2 \mathrm{~ms}$ was used. The signal was acquired only over one rotor period in the indirect dimension and the dipolar dephased signal was extracted for each resolved peak. Simulations of the DIPSHIFT time domain data $g(t)$ were performed using a program written in $\mathrm{C}++$ according to $g(t)=\exp \left\{i \int_{0}^{t} \omega\left(t^{\prime}\right) d t^{\prime}\right\}$ with $\omega(t)=C_{1} \cos \left(\gamma+\omega_{r} t\right)+C_{2} \cos \left(2 \gamma+2 \omega_{r} t\right) . \quad C_{1}=-\delta_{C H} \sqrt{2} / 2 \sin (2 \beta)$ and $\quad C_{2}=1 / 2 \delta_{C H} \sin ^{2} \beta$, with the dipolar coupling strength $\delta_{C H}$, the MAS angular frequency $\omega_{r}$ and the Euler angles $\beta$ and $\gamma$ for powder averaging (Schmidt-Rohr and Spiess 1994). Simulations were performed with $1^{\circ}$ increment for the $\beta$ and $\gamma$ angles. Motionally averaged dipolar coupling values $\left\langle\delta_{C H}\right\rangle$ were determined from the best fit of the dephasing curve to the experimental data. Order parameter were obtained from the equation $S_{C H}=\left\langle\delta_{C H}\right\rangle / \delta_{C H}$, where $\delta_{C H}$ represents the rigid limit value for the dipolar coupling as determined experimentally (Barré et al. 2003b; Huster et al. 2001).

\section{Results}

\section{Static ${ }^{15} \mathrm{~N} C P M A S$ spectra of the $Y 2$ receptor in POPC}

The functionality of the Y2 receptor investigated in this study was shown by using NPY binding assays for receptor preparations in micelles as published before (Bosse et al. 2011). Furthermore, we carried out fluorescence-based ligand binding studies of TAMRA labeled NPY to confirm the high activity of our preparations (see Supplementary Fig. S1). All these experiments typically reported $\sim 90 \pm 10 \%$ of fully binding competent receptor at a subnanomolar $K_{\mathrm{D}}$.

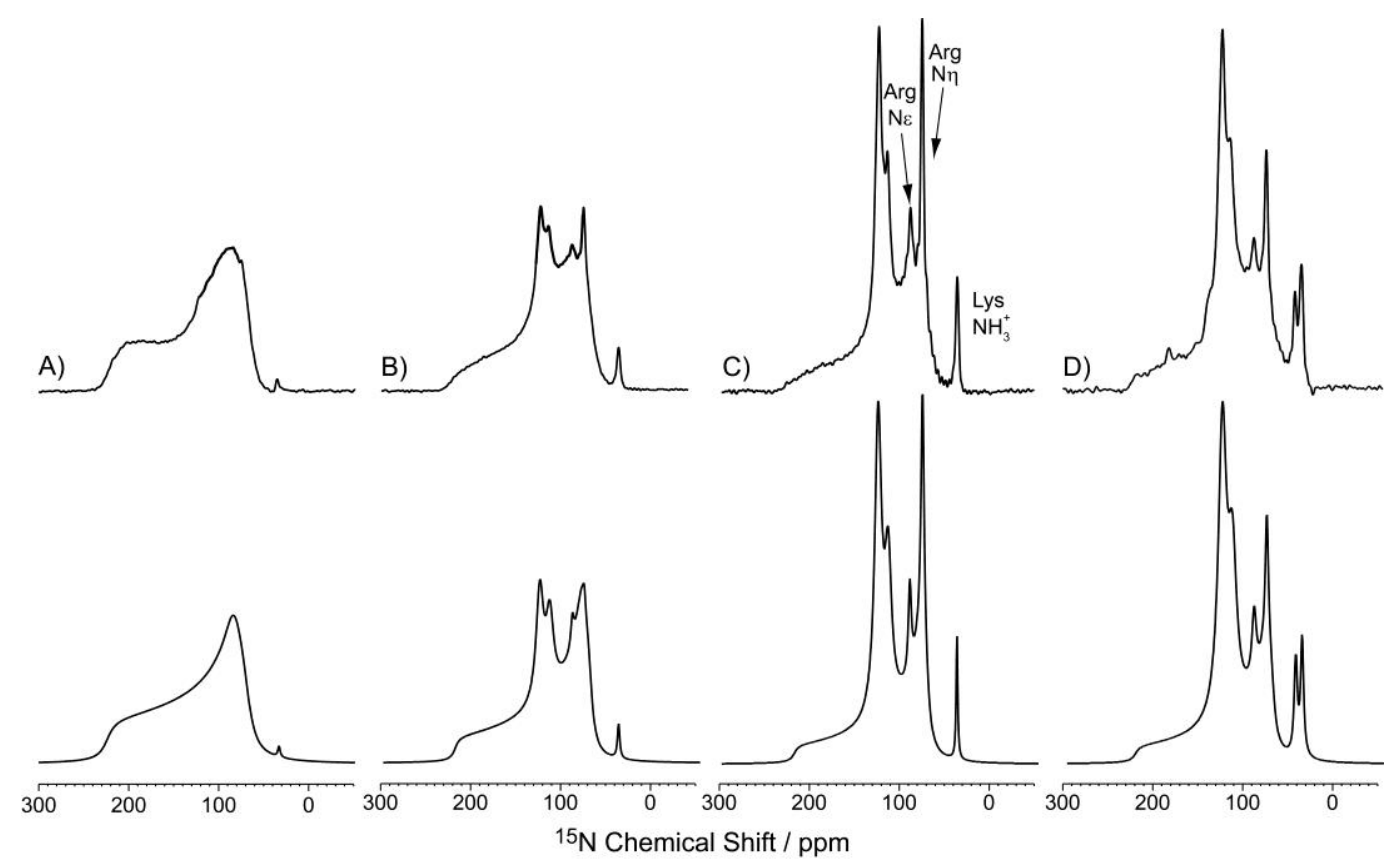

Figure 1: Static ${ }^{15} \mathrm{~N}$ NMR spectra of uniformly ${ }^{15} \mathrm{~N}$-labeled $\mathrm{Y} 2$ receptor reconstituted into POPC membranes at a temperature of $37^{\circ} \mathrm{C}$. Spectra $(A-C)$ were acquired using $C P$ with contact times of $70 \mu \mathrm{s}(A), 2 \mathrm{~ms}(B)$, and $8 \mathrm{~ms}(C)$. Assignment of the prominent side chains is given in the spectrum acquired the longest CP contact time. The spectrum shown in (D) was acquired using direct polarization of a sample containing $\sim 20 \mathrm{mg}{ }^{15} \mathrm{~N}$ labeled $\mathrm{Y} 2$ receptor. In the lower row, best fit numerical simulations of the spectral line shapes are shown. 
We started the investigation of the $\mathrm{Y} 2$ receptor dynamics by recording standard static ${ }^{15} \mathrm{~N}$ cross-polarization (CP) NMR spectra (Opella 1986). From the line shape of these NMR spectra, conclusions about the motional averaging of the ${ }^{15} \mathrm{~N}$ chemical shift tensor of the backbone and side chain amides can be drawn. Fig. 1 shows characteristic static ${ }^{15} \mathrm{~N} \mathrm{NMR}$ spectra of the $\mathrm{U}^{15} \mathrm{~N}$ labeled $\mathrm{Y} 2$ receptor at $37^{\circ} \mathrm{C}$. As reported before (Park et al. 2011; Schmidt et al. 2014), the CP excitation scheme is highly biased by molecular motions, therefore, CP NMR spectra should be recorded for various CP contact times. At a very short $\mathrm{CP}$ contact time of $70 \mu \mathrm{s}$ (Fig. 1A), only the rigid sites that are characterized by high dipolar couplings are efficiently cross polarized. Consequently, the NMR spectrum is indicative of axially symmetric rotational diffusion of the entire receptor in the membrane with span of the ${ }^{15} \mathrm{~N}$ shielding tensor of $\Delta \sigma \approx 155 \mathrm{ppm}$. Only a weak narrow signal from mobile $\mathrm{Lys} \mathrm{NH}_{3}{ }^{+}$ side chains is detected under these conditions. With increasing contact time length, significant alterations of the spectra occur. In addition to the axially symmetric CSA powder spectrum, several isotropic signals are detected, which are indicative of residues undergoing large amplitude fluctuations in their backbone and/or side chain. These mobile residues are detected more efficiently by increasing the CP contact time to $2 \mathrm{~ms}$ (Fig. 1B). In addition to a prominent Lys $\mathrm{NH}_{3}{ }^{+}$peak at $\sim 35 \mathrm{ppm}$, the characteristic $\operatorname{Arg} \mathrm{N} \varepsilon$ and $\operatorname{Arg} \mathrm{N} \eta$ signals at $\sim 89 \mathrm{ppm}$ and $\sim 75 \mathrm{ppm}$ are seen in addition to two isototropic signals in the amide region at $\sim 123$ and $\sim 119 \mathrm{ppm}$. These mobile residues are detected with significantly higher intensity when the $\mathrm{CP}$ contact time is increased to $8 \mathrm{~ms}$ (Fig. 1C), which indicates the dynamic bias of the polarization transfer by $\mathrm{CP}$. The respective line shape simulations are shown in the lower row.

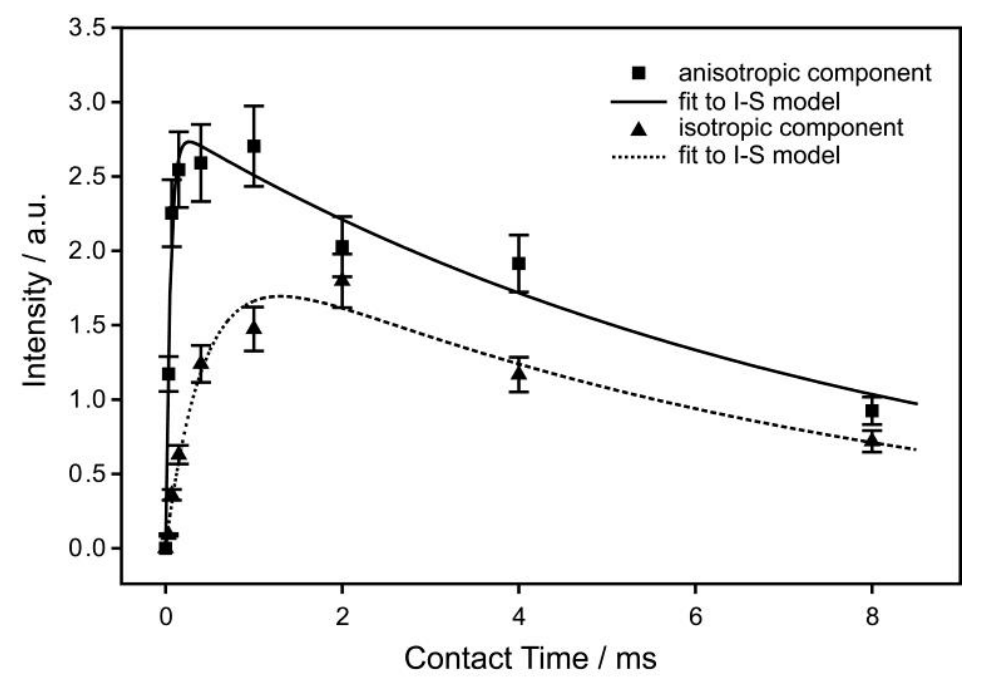

Figure 2: $\mathrm{CP}$ build up curves of the isotropic and anisotropic spectral components of the static ${ }^{15} \mathrm{~N}$ NMR spectra of the Y2 receptor in POPC membranes at a temperature of $37^{\circ} \mathrm{C}$. Lines represent the best fits to the I-S model (Kolodziejski and Klinowski 2002).

In an attempt to quantify the relative amounts of the rigid sites, which give rise to anisotropic ${ }^{15} \mathrm{~N}$ line shapes and highly mobile site, which produce almost isotropic ${ }^{15} \mathrm{~N}$ NMR lines, we recorded a series of static ${ }^{15} \mathrm{~N} N \mathrm{NR}$ spectra with varying CP contact time and fitted these intensities to the classical I-S model (Kolodziejski and Klinowski 2002). Spectral intensities of the isotropic and anisotropic amide lines in the spectra as a function of CP contact time are shown in Fig. 2. From the I-S model, we can determine the $T_{1 \mathrm{p}}$ relaxation times of both contributions, which are relatively similar (7.9 and $7.2 \mathrm{~ms}$ for anisotropic and isotropic sites, respectively). However, as expected and seen in Fig. 2, the CP rate constant 
is much higher for the anisotroic component $\left(1 / T_{\text {IS }}=18.5 \mathrm{kHz}\right)$ than for the isotropic component $(2.3 \mathrm{kHz})$. Most importantly, this analysis provides a semi-quantitative ratio of the number of rigid and highly mobile sites, which amounts to $58 \%$ of the amides in rigid and $42 \%$ in highly mobile conformations.

To confirm this surprising large spectral contribution from highly mobile sites, we performed directly polarized static ${ }^{15} \mathrm{~N}$ NMR experiments. To this end, a sample was prepared that contained $20 \mathrm{mg}$ of $\mathrm{Y} 2$ receptor and directly polarized spectra were acquired with a long relaxation delay of $10 \mathrm{~s}$. The spectrum is shown in Fig. 1D and confirms the large amount of backbone and side chain sites that undergo large amplitude motions. Line shape simulations using our own Mathcad software of the ${ }^{15} \mathrm{~N}$ NMR spectra are also shown in Fig. $1 \mathrm{D}$ and confirm that the receptor undergoes axially symmetric reorientation in the membrane.

\section{${ }^{13} \mathrm{C}$ MAS NMR studies of the mobility of the $\mathrm{Y} 2$ receptor in POPC}

Next, we investigated the dynamics of the membrane reconstituted $\mathrm{Y} 2$ receptor by ${ }^{13} \mathrm{C}$ MAS NMR. Fig. 3 shows characteristic ${ }^{13} \mathrm{C}$ CPMAS (A) and directly excited ${ }^{13} \mathrm{C}$ MAS NMR spectra (B) of the $\mathrm{Y} 2$ receptor in POPC membranes. The resolution of the ${ }^{13} \mathrm{C}$ NMR spectra allows distinguishing the aliphatic $\mathrm{CH}, \mathrm{CH}_{2}$, and $\mathrm{CH}_{3}$ carbons, but signals tend to be relatively broad. Subtle differences between ${ }^{13} \mathrm{C}$ CPMAS and directly excited MAS spectra suggest that parts of the Y2 receptor may undergo large amplitude motions in the membrane. In particular, the $\mathrm{CO}$ region shows sharp lines in the directly excited spectrum compared to the CPMAS spectra. This is also observed for the $\mathrm{CH}_{2}$ region. ${ }^{13} \mathrm{C}$ INEPT spectra also showed numerous narrow signals, but the NMR spectrum was dominated by the ${ }^{13} \mathrm{C}$ NMR signals from the POPC membrane at natural abundance (not shown).

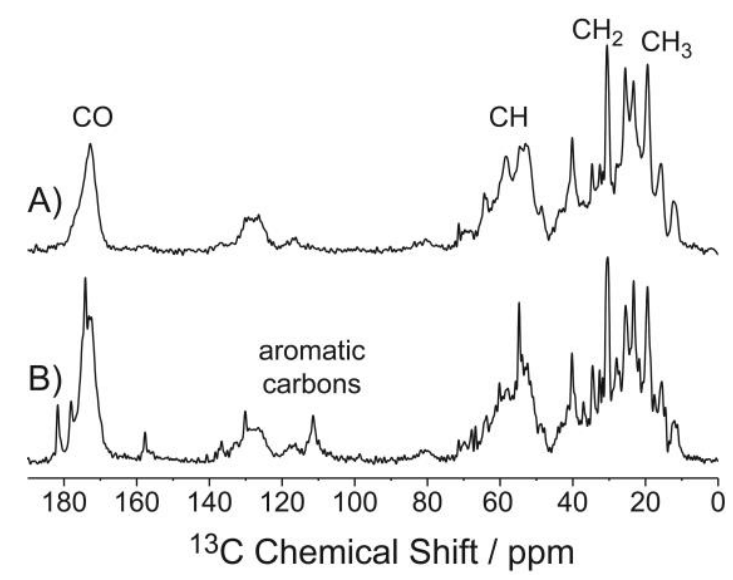

Figure $3:{ }^{13} \mathrm{C}$ MAS NMR spectra of the uniformly ${ }^{13} \mathrm{C}$-labeled $\mathrm{Y} 2$ receptor reconstituted into POPC membranes using different ${ }^{13} \mathrm{C}$ excitation pulse sequences. A) ${ }^{13} \mathrm{C}$ CPMAS spectrum using a CP contact time of $0.7 \mathrm{~ms}, \mathrm{~B}$ ) directly excited ${ }^{13} \mathrm{C}$ MAS NMR spectrum. All spectra were recorded at $37^{\circ} \mathrm{C}$ at a MAS frequency of $7 \mathrm{kHz}$ using Spinal64 decoupling with a radio frequency amplitude of $\sim 65 \mathrm{kHz}$.

${ }^{13} \mathrm{C}$ MAS NMR also provides the means to study the molecular mobility of the $\mathrm{Y} 2$ receptor more quantitatively with some site resolution by measuring the motionally averaged ${ }^{1} \mathrm{H}^{13} \mathrm{C}$ dipolar couplings using the separated local field experiment DIPSHIFT (Munowitz et al. 1981). All motions with correlation times up to microseconds average the ${ }^{1} \mathrm{H}_{-}^{13} \mathrm{C}$ dipolar tensors and can be detected in DIPSHIFT experiments. ${ }^{1} \mathrm{H}^{13} \mathrm{C}$ dipolar couplings partially averaged by molecular motions lead to a less pronounced dephasing in the DIPSHIFT time domain data. Fig. 4 shows some characteristic experimental dephasing curves for backbone 
and sidechain sites of the $\mathrm{Y} 2$ receptor in POPC and the numerical simulations used to determine the respective dipolar coupling value for a number of CP contact time as well as for direct polarization of ${ }^{13} \mathrm{C}$. The ratio of motionally averaged and full dipolar coupling defines an order parameter for the $\mathrm{H}-\mathrm{C}$ bond vector that ranges from 0 for isotropic mobility to 1 for rigidity. Order parameters could be determined for various resolved peaks in the ${ }^{13} \mathrm{C}$ MAS NMR spectra characteristic of the backbone $\mathrm{CH}$ region, the resolved Gly residues, and the $\mathrm{CH}_{2}$ as well as the $\mathrm{CH}_{3}$ side chains.

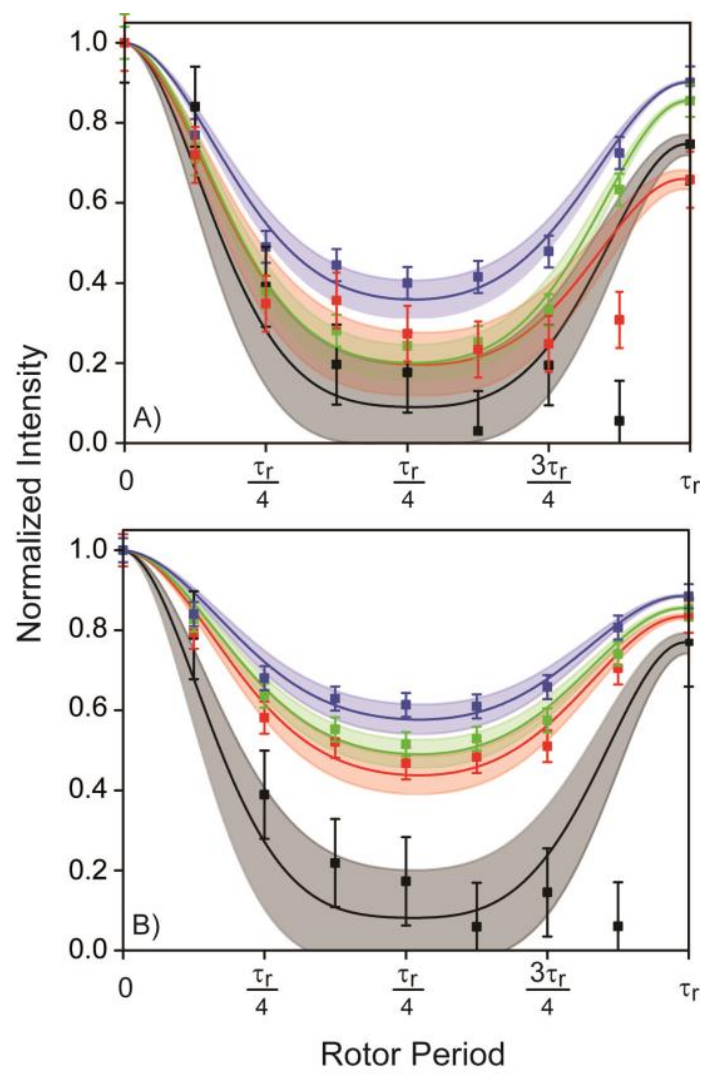

Figure 4: DIPSHIFT dephasing curves of the $\mathrm{C} \alpha$ region (A) and a $\mathrm{CH}_{2}$ side chain signal at $40 \mathrm{ppm}(\mathrm{B})$ of the $\mathrm{Y} 2$ receptor in POPC membranes determined for a CP contact time of $20 \mu \mathrm{s}$ (black), $700 \mu \mathrm{s}$ (red), $2 \mathrm{~ms}$ (green) and by direct polarization (blue). The shaded areas correspond to the error margin in the determination of the order parameter as given in Table 1 . The temperature of the measurement was $37^{\circ} \mathrm{C}$.

Fig. 5 shows a plot of the segmental order parameters of the Y2 receptor in POPC membranes at $37^{\circ} \mathrm{C}$. As observed for the static ${ }^{15} \mathrm{~N}$ spectra, the choice of the $\mathrm{CP}$ contact time length allows distinguishing between more rigid and more mobile sites. At a short $\mathrm{CP}$ contact time of $20 \mu \mathrm{s}$, order parameters are relatively high for all backbone and side chain signals (0.79-0.89 for backbone sites, $0.61-0.76$ for the $\mathrm{CH}_{2}$, and 0.42 for $\mathrm{CH}_{3}$ side chains). Upon increasing the $\mathrm{CP}$ contact time to $0.7 \mathrm{~ms}$, also the more mobile sites are sufficiently cross-polarized and contribute to the spectral intensity, resulting in a decrease in the order parameters. At a long contact time of $2 \mathrm{~ms}$, the order parameters are comparable to those detected at $700 \mu$ s contact time for all investigated sites. In order to excite all residues of the Y2 receptor homogeneously, directly excited DIPSHIFT experiments were also carried out. These directly excited DIPSHIFT spectra provide an unbiased view of the average receptor dynamics. Under these conditions, the lowest order parameters of $0.56-0.65$ are detected for the protein backbone, while side chains exhibit order parameters between 0.26 and 0.40 for the $\mathrm{CH}_{2}$ and 0.20 for the $\mathrm{CH}_{3}$ segments of the protein side chains. Table 1 
provides an overview of all order parameter measurements at all temperatures investigated.

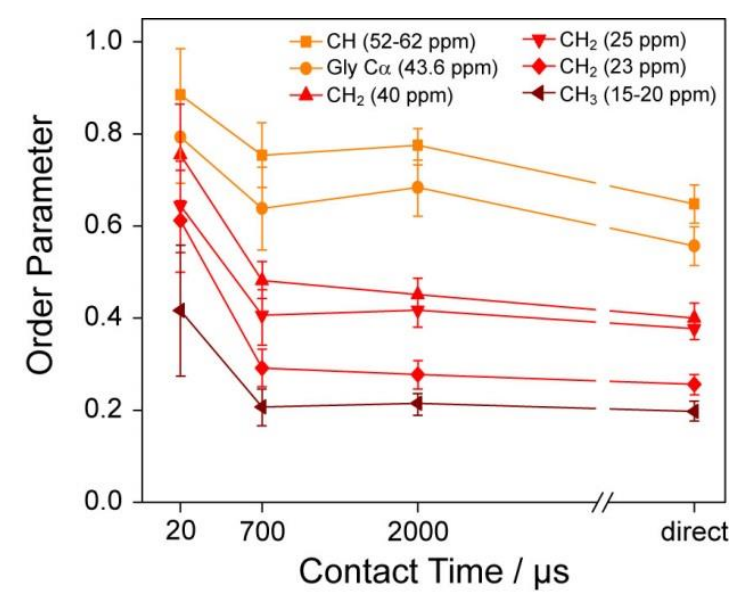

Figure $5:{ }^{13} \mathrm{C}$ NMR order parameters for backbone and side-chain carbons of the uniformly ${ }^{13} \mathrm{C}$ labeled Y2 receptor reconstituted into POPC membranes at varying $\mathrm{CP}$ contact times at a temperature of $37^{\circ} \mathrm{C}$. $\mathrm{C}-\mathrm{H}$ dipolar coupling constants were measured using DIPSHIFT experiments and averaged over several signals in the same ${ }^{13} \mathrm{C}$ chemical shift region or for specific peaks.

We also studied the temperature dependence of these $\mathrm{Y} 2$ order parameters between $-30^{\circ} \mathrm{C}$ and $55^{\circ} \mathrm{C}$ (Table 1). It is remarkable that the logarithm of the order parameter is proportional to the inverse temperature and that the main phase transition of the POPC membrane at $-2^{\circ} \mathrm{C}$ does not interfere with this behavior. 
Table 1: DIPSHIFT order parameters of uniformly ${ }^{13} \mathrm{C}$-labeled $\mathrm{Y}_{2}$ receptor reconstituted into POPC membranes at different temperatures and $\mathrm{CP}$ contact times

\begin{tabular}{|c|c|c|c|c|c|c|c|c|c|c|c|}
\hline Temperature: & $-30^{\circ} \mathrm{C}$ & $5^{\circ} \mathrm{C}$ & \multicolumn{4}{|c|}{$23^{\circ} \mathrm{C}$} & \multicolumn{4}{|c|}{$37^{\circ} \mathrm{C}$} & \multirow{2}{*}{$\begin{array}{r}55^{\circ} \mathrm{C} \\
700 \mu \mathrm{s}\end{array}$} \\
\hline $\begin{array}{c}\text { CP contact } \\
\text { time: }\end{array}$ & $700 \mu \mathrm{s}$ & $700 \mu \mathrm{s}$ & $20 \mu \mathrm{s}$ & $700 \mu \mathrm{s}$ & $2 \mathrm{~ms}$ & direct & $20 \mu \mathrm{s}$ & $700 \mu \mathrm{s}$ & $2 \mathrm{~ms}$ & direct & \\
\hline $\begin{array}{c}\mathrm{CH} \\
(52-62 \mathrm{ppm})\end{array}$ & $\begin{array}{c}0.90 \pm \\
0.04 \\
\end{array}$ & $\begin{array}{c}0.81 \pm \\
0.04\end{array}$ & $\begin{array}{c}0.90 \pm \\
0.05\end{array}$ & $\begin{array}{c}0.78 \pm \\
0.04 \\
\end{array}$ & $\begin{array}{c}0.81 \pm \\
0.04 \\
\end{array}$ & $\begin{array}{c}0.67 \pm \\
0.04\end{array}$ & $\begin{array}{c}0.89 \pm \\
0.10\end{array}$ & $\begin{array}{c}0.75 \pm \\
0.07 \\
\end{array}$ & $\begin{array}{c}0.78 \pm \\
0.04\end{array}$ & $\begin{array}{c}0.65 \pm \\
0.04 \\
\end{array}$ & $\begin{array}{c}0.78 \pm \\
0.04\end{array}$ \\
\hline $\begin{array}{c}\text { Gly } \\
\text { (43.6 ppm) }\end{array}$ & $\begin{array}{c}0.82 \pm \\
0.04 \\
\end{array}$ & $\begin{array}{c}0.74 \pm \\
0.04 \\
\end{array}$ & $\begin{array}{c}0.80 \pm \\
0.05\end{array}$ & $\begin{array}{c}0.71 \pm \\
0.04 \\
\end{array}$ & $\begin{array}{c}0.71 \pm \\
0.07 \\
\end{array}$ & $\begin{array}{c}0.59 \pm \\
0.05\end{array}$ & $\begin{array}{c}0.79 \pm \\
0.10 \\
\end{array}$ & $\begin{array}{c}0.64 \pm \\
0.09 \\
\end{array}$ & $\begin{array}{c}0.68 \pm \\
0.06 \\
\end{array}$ & $\begin{array}{c}0.56 \pm \\
0.04 \\
\end{array}$ & $\begin{array}{c}0.67 \pm \\
0.04\end{array}$ \\
\hline $\mathrm{CH}_{2}(40 \mathrm{ppm})$ & $\begin{array}{c}0.79 \pm \\
0.04 \\
\end{array}$ & $\begin{array}{c}0.54 \pm \\
0.03 \\
\end{array}$ & $\begin{array}{c}0.78 \pm \\
0.07 \\
\end{array}$ & $\begin{array}{c}0.51 \pm \\
0.03 \\
\end{array}$ & $\begin{array}{c}0.47 \pm \\
0.03 \\
\end{array}$ & $\begin{array}{c}0.43 \pm \\
0.04 \\
\end{array}$ & $\begin{array}{c}0.76 \pm \\
0.11 \\
\end{array}$ & $\begin{array}{c}0.48 \pm \\
0.04 \\
\end{array}$ & $\begin{array}{c}0.45 \pm \\
0.03 \\
\end{array}$ & $\begin{array}{c}0.40 \pm \\
0.03 \\
\end{array}$ & $\begin{array}{c}0.49 \pm \\
0.03\end{array}$ \\
\hline $\mathrm{CH}_{2}(25 \mathrm{ppm})$ & $\begin{array}{c}0.52 \pm \\
0.03 \\
\end{array}$ & $\begin{array}{c}0.48 \pm \\
0.02 \\
\end{array}$ & $\begin{array}{c}0.63 \pm \\
0.09 \\
\end{array}$ & $\begin{array}{c}0.45 \pm \\
0.03 \\
\end{array}$ & $\begin{array}{c}0.44 \pm \\
0.03 \\
\end{array}$ & $\begin{array}{c}0.41 \pm \\
0.02\end{array}$ & $\begin{array}{c}0.64 \pm \\
0.10\end{array}$ & $\begin{array}{c}0.44 \pm \\
0.06 \\
\end{array}$ & $\begin{array}{c}0.42 \pm \\
0.03 \\
\end{array}$ & $\begin{array}{c}0.38 \pm \\
0.02 \\
\end{array}$ & $\begin{array}{c}0.43 \pm \\
0.03\end{array}$ \\
\hline $\mathrm{CH}_{2}(23 \mathrm{ppm})$ & $\begin{array}{c}0.39 \pm \\
0.02 \\
\end{array}$ & $\begin{array}{c}0.35 \pm \\
0.02 \\
\end{array}$ & $\begin{array}{c}0.63 \pm \\
0.09 \\
\end{array}$ & $\begin{array}{c}0.41 \pm \\
0.03 \\
\end{array}$ & $\begin{array}{c}0.36 \pm \\
0.02 \\
\end{array}$ & $\begin{array}{c}0.28 \pm \\
0.02 \\
\end{array}$ & $\begin{array}{c}0.61 \pm \\
0.11 \\
\end{array}$ & $\begin{array}{c}0.29 \pm \\
0.04 \\
\end{array}$ & $\begin{array}{c}0.28 \pm \\
0.03 \\
\end{array}$ & $\begin{array}{c}0.26 \pm \\
0.02\end{array}$ & $\begin{array}{c}0.30 \pm \\
0.02 \\
\end{array}$ \\
\hline $\begin{array}{c}\mathrm{CH}_{3} \\
(15-20 \mathrm{ppm})\end{array}$ & $\begin{array}{c}0.27 \pm \\
0.02 \\
\end{array}$ & $\begin{array}{c}0.24 \pm \\
0.01 \\
\end{array}$ & $\begin{array}{c}0.41 \pm \\
0.08 \\
\end{array}$ & $\begin{array}{c}0.25 \pm \\
0.02\end{array}$ & $\begin{array}{c}0.23 \pm \\
0.02 \\
\end{array}$ & $\begin{array}{c}0.22 \pm \\
0.01\end{array}$ & $\begin{array}{c}0.42 \pm \\
0.14\end{array}$ & $\begin{array}{c}0.21 \pm \\
0.04 \\
\end{array}$ & $\begin{array}{c}0.22 \pm \\
0.02 \\
\end{array}$ & $\begin{array}{c}0.20 \pm \\
0.02 \\
\end{array}$ & $\begin{array}{c}0.23 \pm \\
0.02\end{array}$ \\
\hline
\end{tabular}




\section{Order parameter measurements of the Y2 receptor in POPC/cholesterol membranes}

Cholesterol is an essential and highly abundant component of biological membranes. The sterol is known to increase the lipid chain order due to favorable van der Waals interactions between the sterol ring structure and the sidechain with preferentially saturated phospholipid chains (Huster et al. 1998; Scheidt et al. 2013). In addition, cholesterol appears to influence the activity of many GPCRs (Oates et al. 2012) and several crystal structures have identified directly bound cholesterol molecules (Cherezov et al. 2007). Here, we investigated the influence of cholesterol on the dynamics of the human Y2 receptor. Table 2 reports the order parameters of the $Y 2$ receptor reconstituted in POPC membranes in the presence of $30 \mathrm{~mol} \%$ cholesterol at various temperatures. At very short $\mathrm{CP}$ contact times, high order parameters are measured, which decrease for longer contact times. Significantly lower order parameters are determined when the carbons were directly polarized in DIPSHIFT experiments. In most cases, within experimental error no differences in the order parameters were observed in the presence of cholesterol as deduced from Fig. 6. At a short contact time of $20 \mu \mathrm{s}$, almost identically high order parameters are measured indicating that the rigid segments of the $\mathrm{Y} 2$ receptor do not respond to the more rigid lipid matrix surrounding the receptor or a possible direct interaction between the two molecules (Table 2). At 700 us contact time, most sites investigated show 10-15\% higher order parameters, while the differences are more moderate and typically not significant at $2 \mathrm{~ms}$ contact time and directly excited DIPSHIFT experiments.

Table 2: DIPSHIFT order parameters of uniformly ${ }^{13} \mathrm{C}$-labeled $\mathrm{Y}_{2}$ receptor reconstituted into POPC/cholesterol $(70 / 30, \mathrm{~mol} / \mathrm{mol})$ membranes at different temperatures and CP contact times

\begin{tabular}{|c|c|c|c|c|c|c|c|c|}
\hline Temperature: & $-30^{\circ} \mathrm{C}$ & $5^{\circ} \mathrm{C}$ & $23^{\circ} \mathrm{C}$ & \multicolumn{4}{|c|}{$37^{\circ} \mathrm{C}$} & $55^{\circ} \mathrm{C}$ \\
\hline $\begin{array}{l}\text { CP contact } \\
\text { time: }\end{array}$ & $700 \mu \mathrm{s}$ & $700 \mu \mathrm{s}$ & $700 \mu \mathrm{s}$ & $20 \mu \mathrm{s}$ & $700 \mu \mathrm{s}$ & $2 \mathrm{~ms}$ & direct & $700 \mu s$ \\
\hline $\begin{array}{c}\mathrm{CH} \\
(52-62 \mathrm{ppm})\end{array}$ & $\begin{array}{c}0.90 \pm \\
0.05\end{array}$ & $\begin{array}{c}0.83 \pm \\
0.08\end{array}$ & $\begin{array}{c}0.82 \pm \\
0.05\end{array}$ & $\begin{array}{c}0.91 \pm \\
0.08\end{array}$ & $\begin{array}{c}0.85 \pm \\
0.04\end{array}$ & $\begin{array}{c}0.82 \pm \\
0.05\end{array}$ & $\begin{array}{c}0.67 \pm \\
0.05\end{array}$ & $\begin{array}{c}0.81 \pm \\
0.04\end{array}$ \\
\hline $\begin{array}{c}\text { Gly } \\
\text { (43.6 ppm) }\end{array}$ & $\begin{array}{c}0.86 \pm \\
0.08\end{array}$ & $\begin{array}{c}0.71 \pm \\
0.08\end{array}$ & $\begin{array}{c}0.72 \pm \\
0.08\end{array}$ & $\begin{array}{c}0.80 \pm \\
0.10\end{array}$ & $\begin{array}{c}0.69 \pm \\
0.08\end{array}$ & $\begin{array}{c}0.66 \pm \\
0.05\end{array}$ & $\begin{array}{c}0.61 \pm \\
0.07\end{array}$ & $\begin{array}{c}0.66 \pm \\
0.07\end{array}$ \\
\hline $\mathrm{CH}_{2}(40 \mathrm{ppm})$ & $\begin{array}{c}0.75 \pm \\
0.07\end{array}$ & $\begin{array}{c}0.48 \pm \\
0.05\end{array}$ & $\begin{array}{c}0.50 \pm \\
0.07\end{array}$ & $\begin{array}{c}0.77 \pm \\
0.14 \\
\end{array}$ & $\begin{array}{c}0.50 \pm \\
0.05\end{array}$ & $\begin{array}{c}0.44 \pm \\
0.05\end{array}$ & $\begin{array}{c}0.36 \pm \\
0.03\end{array}$ & $\begin{array}{c}0.45 \pm \\
0.04 \\
\end{array}$ \\
\hline $\mathrm{CH}_{2}(25 \mathrm{ppm})$ & $\begin{array}{c}0.47 \pm \\
0.03\end{array}$ & $\begin{array}{c}0.49 \pm \\
0.04\end{array}$ & $\begin{array}{c}0.48 \pm \\
0.03\end{array}$ & $\begin{array}{c}0.66 \pm \\
0.16\end{array}$ & $\begin{array}{c}0.47 \pm \\
0.05\end{array}$ & $\begin{array}{c}0.46 \pm \\
0.05\end{array}$ & $\begin{array}{c}0.37 \pm \\
0.03\end{array}$ & $\begin{array}{c}0.43 \pm \\
0.03\end{array}$ \\
\hline $\mathrm{CH}_{2}(23 \mathrm{ppm})$ & $\begin{array}{c}0.47 \pm \\
0.03\end{array}$ & $\begin{array}{c}0.34 \pm \\
0.03\end{array}$ & $\begin{array}{c}0.33 \pm \\
0.03\end{array}$ & $\begin{array}{c}0.62 \pm \\
0.20\end{array}$ & $\begin{array}{c}0.32 \pm \\
0.03\end{array}$ & $\begin{array}{c}0.28 \pm \\
0.03\end{array}$ & $\begin{array}{c}0.26 \pm \\
0.02\end{array}$ & $\begin{array}{c}0.29 \pm \\
0.02 \\
\end{array}$ \\
\hline $\begin{array}{c}\mathrm{CH}_{3} \\
(15-20 \mathrm{ppm})\end{array}$ & $\begin{array}{c}0.28 \pm \\
0.02\end{array}$ & $\begin{array}{c}0.24 \pm \\
0.02\end{array}$ & $\begin{array}{c}0.24 \pm \\
0.02\end{array}$ & $\begin{array}{c}0.42 \pm \\
0.22\end{array}$ & $\begin{array}{c}0.24 \pm \\
0.03\end{array}$ & $\begin{array}{c}0.22 \pm \\
0.03\end{array}$ & $\begin{array}{c}0.21 \pm \\
0.02\end{array}$ & $\begin{array}{c}0.23 \pm \\
0.02\end{array}$ \\
\hline
\end{tabular}

\section{Order parameter measurements of the Y2 receptor in POPC/POPS membranes}

Negatively charged phospholipids also represent an integral component of natural membranes. Therefore, we reconstituted the $\mathrm{Y} 2$ receptor into POPC/POPS membranes at a molar mixing ratio of $80 / 20$. Order parameters determined for several segments of the $Y 2$ receptor in POPC/POPS membranes at $37^{\circ} \mathrm{C}$ measured in DIPSHIFT experiments using varying CP contact times or direct ${ }^{13} \mathrm{C}$ excitation are reported in Table 3. Again, our measurements show that the $\mathrm{Y} 2$ receptor undergoes relatively large amplitude motions also in these mixed membranes. Again, within experimental error of $5-10 \%$, identical order parameters were observed in the mixed membrane compared to pure POPC, which is displayed in Fig. 6. 
Table 3: DIPSHIFT order parameters of uniformly ${ }^{13} \mathrm{C}$-labeled $\mathrm{Y}_{2}$ receptor reconstituted into POPC/POPS (80/20, $\mathrm{mol} / \mathrm{mol}$ ) membranes at $37^{\circ} \mathrm{C}$ and varying $\mathrm{CP}$ contact times

\begin{tabular}{|c|c|c|c|c|}
\hline Temperature: & \multicolumn{4}{|c|}{$37^{\circ} \mathrm{C}$} \\
\hline $\begin{array}{c}\mathrm{CP} \text { contact } \\
\text { time: }\end{array}$ & $20 \mu \mathrm{s}$ & $700 \mu \mathrm{s}$ & $2 \mathrm{~ms}$ & direct \\
\hline $\begin{array}{c}\mathrm{CH} \\
(52-62 \mathrm{ppm})\end{array}$ & 0.87 & 0.78 & 0.77 & 0.65 \\
\hline $\begin{array}{c}\mathrm{Gly} \\
(43.6 \mathrm{ppm})\end{array}$ & 0.78 & 0.68 & 0.72 & 0.54 \\
\hline $\mathrm{CH}_{2}(40 \mathrm{ppm})$ & 0.74 & 0.45 & 0.43 & 0.38 \\
\hline $\mathrm{CH}_{2}(25 \mathrm{ppm})$ & 0.58 & 0.41 & 0.40 & 0.37 \\
\hline $\mathrm{CH}_{2}(23 \mathrm{ppm})$ & 0.59 & 0.30 & 0.26 & 0.24 \\
\hline $\begin{array}{c}\mathrm{CH} \\
(15-20 \mathrm{ppm})\end{array}$ & 0.40 & 0.23 & 0.20 & 0.18 \\
\hline
\end{tabular}
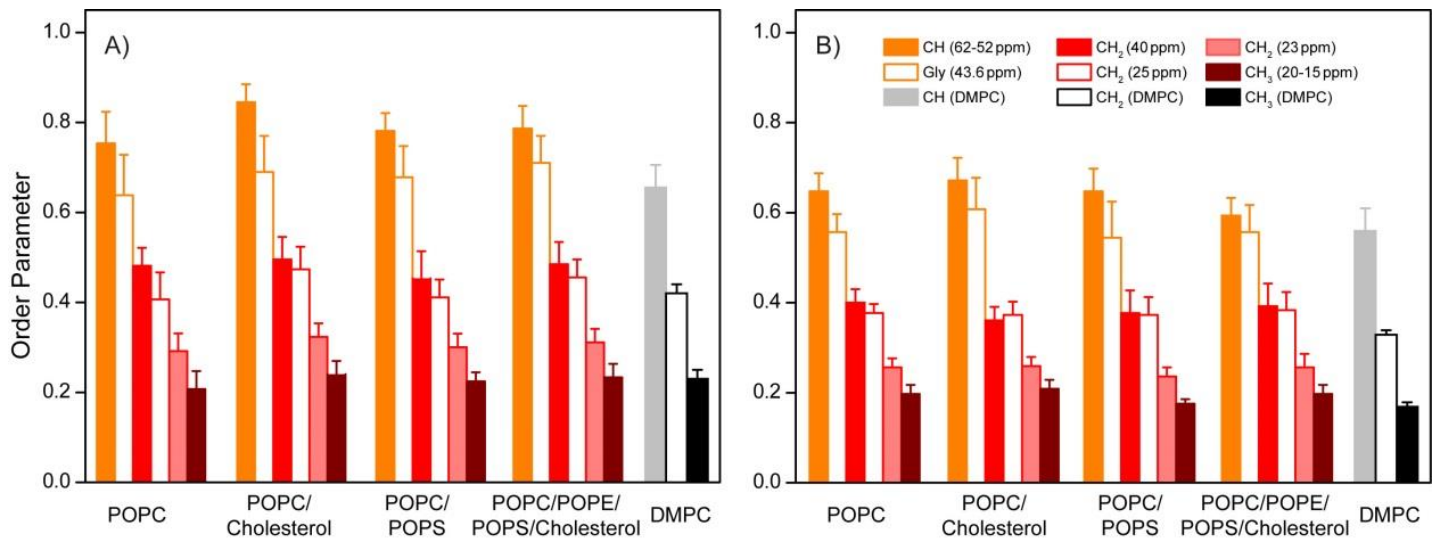

Figure 6: Summary of the order parameter measurements performed this study. Order parameters were determined from DIPSHIFT experiments conducted using CP excitation with a CP contact time of $700 \mu \mathrm{s}(\mathrm{A})$ or direct excitation (B) at a temperature of $37^{\circ} \mathrm{C}$. The bars shown in gray scale indicate the order parameters measured in a DMPC host membrane under the same experimental conditions (Schmidt et al. 2014).

\section{Order parameter measurements of the $\mathrm{Y} 2$ receptor in POPC/POPE/POPS/cholesterol membranes}

Phosphatidylethanolamine represents a highly relevant lipid for GPCR-interaction due to its high negative intrinsic curvature (Botelho et al. 2006; Soubias et al. 2006). To probe the influence of POPE, we prepared a quaternary mixture of lipids relevant to neuronal membranes (Huster et al. 1998; Huster et al. 2000). The molar ratio of POPC/POPE/POPS/cholesterol was 40/40/10/10. The determined order parameters for varying $\mathrm{CP}$ contact times and direct polarization at $37^{\circ} \mathrm{C}$ are shown in Table 4 . For direct comparison with all other lipid mixtures studied, the bar diagram in Fig. 6 reveals that also the addition of POPE did not result in a significant changes in the order parameters. 
Table 4: DIPSHIFT order parameters of uniformly ${ }^{13} \mathrm{C}$-labeled $\mathrm{Y}_{2}$ receptor reconstituted into $\mathrm{POPC} / \mathrm{POPE} / \mathrm{POPS} / \mathrm{cholesterol}(40 / 40 / 10 / 10, \mathrm{~mol} / \mathrm{mol} / \mathrm{mol} / \mathrm{mol})$ membranes at $37^{\circ} \mathrm{C}$ and varying $\mathrm{CP}$ contact times

\begin{tabular}{|c|c|c|c|c|}
\hline Temperature: & \multicolumn{4}{|c|}{$37^{\circ} \mathrm{C}$} \\
\hline $\mathrm{CP}$ contact & $20 \mu \mathrm{s}$ & $700 \mu \mathrm{s}$ & $2 \mathrm{~ms}$ & direct \\
time: & & & & \\
\hline $\mathrm{CH}$ & $0.98 \pm$ & $0.79 \pm$ & $0.78 \pm$ & $0.59 \pm$ \\
$(52-62 \mathrm{ppm})$ & 0.19 & 0.05 & 0.05 & 0.04 \\
\hline $\mathrm{Gly}$ & $0.83 \pm$ & $0.71 \pm$ & $0.74 \pm$ & $0.56 \pm$ \\
$(43.6 \mathrm{ppm})$ & 0.17 & 0.06 & 0.09 & 0.06 \\
\hline $\mathrm{CH}_{2}(40 \mathrm{ppm})$ & $0.82 \pm$ & $0.48 \pm$ & $0.46 \pm$ & $0.39 \pm$ \\
& 0.20 & 0.05 & 0.05 & 0.05 \\
\hline $\mathrm{CH}_{2}(25 \mathrm{ppm})$ & $0.68 \pm$ & $0.46 \pm$ & $0.44 \pm$ & $0.38 \pm$ \\
& 0.22 & 0.04 & 0.04 & 0.04 \\
\hline $\mathrm{CH}_{2}(23 \mathrm{ppm})$ & $0.66 \pm$ & $0.31 \pm$ & $0.28 \pm$ & $0.26 \pm$ \\
& 0.25 & 0.03 & 0.03 & 0.03 \\
\hline $\mathrm{CH}_{3}$ & $0.44 \pm$ & $0.23 \pm$ & $0.21 \pm$ & $0.20 \pm$ \\
$(15-20 \mathrm{ppm})$ & 0.24 & 0.03 & 0.03 & 0.02 \\
\hline
\end{tabular}

\section{Discussion}

Equilibrium dynamics represents a characteristic feature of many biological molecules and appears to play an important role for several GPCRs. Most quantitative data so far comes from EPR studies involving site-directed spin labeling of bovine rhodopsin (Hubbell et al. 2003). The fact that GPCRs have eluded crystallization for a long time can at least in part also be related to the dynamic nature of these molecules. Consequently, most GPCRs have only been crystallized by massive immobilization of the molecule by anti- or nanobody binding, by replacing or removing loops, or by thermostabilization through mutations (Venkatakrishnan et al. 2013). Furthermore, the crystal structures show relatively high B factors, ranging from $30-120 \AA^{2}$ for the transmembrane helices to $100-280 \AA^{2}$ for the loops and termini.

Solid-state NMR has unique capabilities to study the dynamics of biomolecules (Huster 2005; Palmer III et al. 1996; Reichert 2005). In the GPCR field, the CXCR1 receptor reconstituted into DMPC/POPC (80/20) has been found to undergo fast local backbone motions only for residues near the $\mathrm{N}$ - and $\mathrm{C}$-terminus but not for the transmembrane helices or interhelical loops in addition to rapid global rotational diffusion (Park et al. 2011). In contrast, in a previous study, the Y2 receptor in DMPC was found to be highly dynamic with large amplitude segmental fluctuations in addition to the axially symmetric rotation in the bilayer (Schmidt et al. 2014). In the current study, we have investigated the molecular mobility of the full length human neuropeptide $\mathrm{Y} 2$ receptor reconstituted into monounsaturated POPC membranes by solid-state NMR spectroscopy. The influence of the physiologically relevant lipids cholesterol and POPS on the equilibrium dynamics of the Y2 receptor was further evaluated.

Already the static ${ }^{15} \mathrm{~N}$ CP NMR spectra show the pronounced molecular mobility of the Y2 receptor in POPC membranes (Fig. 1). The static ${ }^{15} \mathrm{~N} N M R$ spectra of the $\mathrm{Y} 2$ receptor in membranes are dominated by axially symmetric motions of the whole molecule. In addition to the rotation of the entire $\mathrm{Y} 2$ receptor, segmental motions with large amplitudes have been observed that give rise to isotropic signals in static ${ }^{15} \mathrm{~N} \mathrm{CP} \mathrm{NMR} \mathrm{spectra} \mathrm{both} \mathrm{in} \mathrm{the}$ side chains and in the backbone. As polarization transfer by $\mathrm{CP}$ is biased towards rigid 
residues that feature large dipolar couplings, CP build up curves as a function of contact times had to be employed to quantify the more mobile sites (Fig. 2). Applying the I-S model (Kolodziejski and Klinowski 2002) revealed that the ratio of rigid to highly mobile backbone amides is about 58/42. This surprisingly high number of highly mobile sites in the Y2 receptor was confirmed by directly polarized static ${ }^{15} \mathrm{~N}$ NMR experiments (Fig. 1D).

Quantitative dynamics information is available from direct ${ }^{1} \mathrm{H}^{13} \mathrm{C}$ dipolar coupling measurements. As with the static ${ }^{15} \mathrm{~N}$ NMR spectra, the $\mathrm{CP}$ contact time is the decisive factor in the investigation of the more mobile site as for residues undergoing large amplitude motions the dipolar couplings are significantly reduced rendering $\mathrm{CP}$ a rather inefficient method for polarization transfer for such mobile sites. Consequently, the determined order parameters decrease upon increase in the contact time length. Lowest order parameters of the $\mathrm{Y} 2$ receptor in POPC were determined for directly polarized ${ }^{13} \mathrm{C}$ DIPSHIFT experiments (0.59-0.67 for the protein backbone, 0.41-0.51 for the $\mathrm{CH}_{2}$ and 0.22 for the $\mathrm{CH}_{3}$ segments in the side chains). These $\mathrm{Y} 2$ receptor order parameters in the POPC membrane are $\sim 20-30 \%$ higher than what has been measured for this receptor in DMPC (Schmidt et al. 2014), which is at first sight surprising as the monounsaturated POPC forms a much more mobile membrane than the saturated DMPC (Vogel et al. 2009). However, POPC also shows an increased hydrophobic thickness of $28.6 \AA$ vs. $25.8 \AA$ for DMPC at $30^{\circ} \mathrm{C}$ (Vogel et al. 2009) and the receptor molecule has to adapt to the hydrophobic thickness of the respective membrane. In the presence of $30 \mathrm{~mol} \%$ cholesterol, lipid chain order parameters increase further to reach a hydrophobic thickness of $31.6 \AA$ but the Y2 receptor order parameters in the backbone do not increase within experimental error. For bovine rhodopsin, it has been measured that the $\alpha$-helical content of the molecule increases proportionally with the hydrophobic thickness of its host membrane (Soubias et al. 2008). The $\alpha$-helix content increased by $\sim 15 \%$ when rhodopsin was reconstituted into a membrane with 18 carbons in the chain compared to the membrane with 14 carbons in the chain. Therefore, the GPCR may adjust its structure to the thickness of the lipid matrix by increasing the length of the $\alpha$-helices as non-hydrogen bonded polypeptide structures require a significant free energy penalty when inserted into a lipid membrane (Wimley and White 1996). Provided this mechanism also applies for other GPCRs, an increase in $\alpha$-helical content would increase the more rigid transmembrane segments at the cost of the more mobile loop and tail structures and consequently increase the average order parameters of the $\mathrm{Y} 2$ receptor as observed. One may speculate that further increase of the hydrophobic thickness of the membrane as in the presence of cholesterol leaves the $\alpha$-helix content of the $Y 2$ receptor on a similar level in spite of the increased hydrophobic thickness of the membrane.

As membrane induced curvature and hydrophobic forces play a decisive role in the modulation of the activity of GPCRs (Botelho et al. 2006; Teague et al. 2013), we further investigated the influence of other lipid species on the dynamics of the Y2 receptor. Cholesterol is not only an essential component of neural membranes (Huster et al. 1998), specific interactions between cholesterol and GPCRs has been reported in the literature (Cherezov et al. 2007; Prasanna et al. 2014; Soubias and Gawrisch 2012; Warne et al. 2011). Cholesterol rigidifies the lipid membrane as expressed in increased lipid chain order parameters (Scheidt et al. 2013). This leads to a reduction of the cross sectional area of a lipid in the membrane and an increase in the hydrophobic thickness of the bilayer. In order to study how these membrane alterations affect the equilibrium dynamics of the Y2 
receptor, we investigated the influence of cholesterol-containing POPC membranes on the order parameters of the molecule.

Overall, the influence of cholesterol on the equilibrium dynamics of the $\mathrm{Y} 2$ receptor is not paralleled by a significant increase in order parameters (see Fig. 6). The rigid segments, which we specifically detect at a very short CP contact time do not at all respond to cholesterol. Largest order increase is observed at a CP contact time of $700 \mu \mathrm{s}$, but differences are within experimental error. Apparently, under these conditions, segments in a somewhat intermediate motional regime are preferentially detected, which feel the influence of the rigidified lipid matrix most sensitively. One can speculate that such sides include the ends of the transmembrane $\alpha$-helices, which are subject to a more pronounced dynamics (Pester et al. 2013) and are localized in the liquid-water interface of the membrane, which is also rigidified upon the addition of cholesterol. In addition, cholesterol also increases the hydrophobic thickness of the membrane, which could also induce a higher $\alpha$-helix content, which would increase the average order of the molecule. At longer $\mathrm{CP}$ contact time of $2 \mathrm{~ms}$ and in directly polarized DIPSHIFT experiments, the differences between the presence and absence of cholesterol are less pronounced. This agrees with our previous assessment (Schmidt et al. 2014) that the DIPSHIFT experiments recorded at longer $\mathrm{CP}$ contact times or by direct ${ }^{13} \mathrm{C}$ polarization are increasingly sensitive for the loops and tail structures of the molecule, which do not feel the influence of the altered lipid matrix properties due to the presence of cholesterol. Although several specific cholesterol binding sites at GPCRs have been reported (Cherezov et al. 2007), due to the lack of resolution our measurements can not reveal if such specific interactions are also relevant for the $Y 2$ receptor. Although essential components of biological membranes, the effects of POPE or the negatively charged POPS in the membrane on the mobility of the Y2 receptor are not significant.

The current study further confirms that GPCRs are highly mobile molecules with average backbone order parameters of $\leq 0.65$ at $37^{\circ} \mathrm{C}$ when all receptor segments are directly polarized. This experimental regime should abolish the dynamic bias, which is immanent to all CP experiments. However, this property can also help evaluating the heterogeneity in the dynamics of the $\mathrm{Y} 2$ receptor. The high order parameters detected at a very short $\mathrm{CP}$ contact time can be assigned to the transmembrane $\alpha$-helical segments. On average, we detect an order parameter of 0.84 in the protein backbone under these conditions. Depending on the topology model of the $\mathrm{Y} 2$ receptor, $\alpha$-helical segments on the one hand turn and loop structures on the other hand are distributed roughly at a 50/50 ratio. This means that in order to produce an average backbone order parameter of 0.60 as detected in the directly excited DIPSHIFT experiments, the more mobile loop and tail structures would have to exhibit an order parameter of 0.36. Converted into motional amplitude (Palmer III et al. 1996), this would mean that the $\alpha$-helical residues undergo fluctuations with amplitudes on the order of $\sim 25^{\circ}$, while loop and tail structures show motional amplitudes of $\sim 60^{\circ}$ in the backbone.

Such values are significantly lower than what has been found for other membrane embedded proteins. For colicin la, order parameters of 0.88-0.93 have been determined albeit only measured at a contact time of $700 \mu$ s (Huster et al. 2001). Also Anabaena sensory rhodopsins is highly rigid with order parameters $>0.87$ throughout the polypeptide chain as determined from relaxation time analysis (Good et al. 2014). Typical order parameters of pore forming OmpA comprised 0.89 in the transmembrane segments and 
0.66 for the most mobile loop regions, determined by solution NMR (Liang et al. 2010). DIPSHIFT measurements of bacteriorhodopsin from Halobacterium salinarum exhibited methyl group order parameters between 0.25 and 0.35 for the Ala $C \beta$ groups (Barré et al. 2003a), which is also significantly higher than what we observed for the $Y 2$ receptor.

A limitation of the current study is the lacking site resolution of our solid-state NMR spectra of the Y2 receptor in lipid membranes due to the line width and the large number of ${ }^{13} \mathrm{C}$ labeled sites. Consequently, the determined order parameters represent an average over the loops, tails, and transmembrane segments of the receptor. Equilibrium fluctuations show amplitudes of $40-50^{\circ}$ in the backbone and $60-70^{\circ}$ in the side chains (Palmer III et al. 1996). Most of these dynamics are segmental and underline the large intrinsic mobility of the receptor in the membrane. In addition to fluctuations of the individual residues, motions of the transmembrane $\alpha$-helices relative to each other can contribute to the dynamics in this correlation time window.

In conclusion, we demonstrate that the human neuropeptide $\mathrm{Y}$ receptor type 2 is highly mobile when reconstituted into POPC membranes irrespective of other components such as cholesterol or negatively charged lipids. The molecule was found to undergo fast rotational diffusion in the membrane and fluctuations with varying amplitudes including large amplitude motions in the backbone and the side chains. As lipids are known to modulate the intrinsic properties of membrane proteins (Huster 2014), also the dynamics of the $\mathrm{Y} 2$ receptor is somewhat different in a monounsaturated membrane compared to the saturated DMPC bilayer (Schmidt et al. 2014). These equilibrium dynamics reflect the structural plasticity of the molecular that is required for conformational changes upon receptor. On the timescale up to microseconds, on average the motional amplitudes of the receptor backbone and side chain reach values between $\sim 40-50^{\circ}$ and $\sim 60-70^{\circ}$, respectively.

\section{Acknowledgement}

D. H. would like to acknowledge valuable discussions with Profs. D. Reichert and P. K. Madhu. Part of this study was supported by the Europäischer Sozialfonds (ESF 22117016 and 24127009). We would like to thank the group of Annette G. Beck-Sickinger for the TAMRA labeled NPY.

\section{References}

Barré P, Yamaguchi S, Saito H, Huster D (2003a) Backbone dynamics of bacteriorhodopsin as studied by ${ }^{13} \mathrm{C}$ solid-state NMR spectroscopy. Eur Biophys J 32: 578-584.

Barré P, Zschörnig O, Arnold K, Huster D (2003b) Structural and dynamical changes of the bindin B18 peptide upon binding to lipid membranes. A solid-state NMR study. Biochemistry 42: 8377-8386.

Bennett AE, Rienstra CM, Auger M, Lakshmi KV, Griffin RG (1995) Heteronuclear decoupling in rotating solids. J Chem Phys 103: 6951-6958.

Berger C, Montag C, Berndt S, Huster D (2011) Optimization of Escherichia coli cultivation methods for high yield neuropeptide Y receptor type 2 production. Protein Expr Purif 76: 25-35.

Bielecki A, Kolbert AC, Levitt MH (1989) Frequency-switched pulse sequences: homonuclear decoupling and dilute spin NMR in solids. Chem Phys Lett 155: 341-345. 
Bosse M, Thomas L, Hassert R, Beck-Sickinger AG, Huster D, Schmidt P (2011) Assessment of a fully active class A $G$ protein-coupled receptor isolated from in vitro folding. Biochemistry 50: 9817-9825.

Botelho AV, Huber T, Sakmar TP, Brown MF (2006) Curvature and hydrophobic forces drive oligomerization and modulate activity of rhodopsin in membranes. Biophys J 91: 44644477.

Cabrele C, Beck-Sickinger AG (2000) Molecular characterization of the ligand-receptor interaction of the neuropeptide Y family. J Pharm Sci 6: 97-122.

Cherezov V, Rosenbaum DM, Hanson MA, Rasmussen SGF, Thian FS, Kobilka TS, Choi HJ, Kuhn P, Weis WI, Kobilka BK, Stevens RC (2007) High-resolution crystal structure of an engineered human beta(2)-adrenergic G protein-coupled receptor. Science 318: 1258-1265.

Chill JH, Naider F (2011) A solution NMR view of protein dynamics in the biological membrane. Curr Opin Struct Biol 21: 627-633.

Chung KY, Kim TH, Manglik A, Alvares R, Kobilka BK, Prosser RS (2012) Role of detergents in conformational exchange of a G protein-coupled receptor. J Biol Chem 287: 36305-36311.

Columbus L, Hubbell WL (2002) A new spin on protein dynamics. Trends Biochem Sci 27: 288-295.

De Angelis AA, Opella SJ (2007) Bicelle samples for solid-state NMR of membrane proteins. Nat Protoc 2: 2332-2338.

De Paepe G, Lesage A, Emsley L (2003) The performance of phase modulated heteronuclear dipolar decoupling schemes in fast magic-angle-spinning nuclear magnetic resonance experiments. J Chem Phys 119: 4833-4841.

Ding X, Zhao X, Watts A (2013) G-protein-coupled receptor structure, ligand binding and activation as studied by solid-state NMR spectroscopy. Biochem J 450: 443-457.

Frauenfelder H, Sligar SG, Wolynes PG (1991) The energy landscapes and motions of proteins. Science 254: 1598-1603.

Goncalves JA, Ahuja S, Erfani S, Eilers M, Smith SO (2010) Structure and function of G protein-coupled receptors using NMR spectroscopy. Prog Nucl Magn Reson Spectrosc 57: 159-180.

Good DB, Wang S, Ward ME, Struppe J, Brown LS, Lewandowski JR, Ladizhansky V (2014) Conformational dynamics of a seven transmembrane helical protein Anabaena Sensory Rhodopsin probed by solid-state NMR. J Am Chem Soc \%19;136: 2833-2842.

Henzler-Wildman K, Kern D (2007) Dynamic personalities of proteins. Nature 450: 964-972.

Hong M, Zhang Y, Hu F (2012) Membrane protein structure and dynamics from NMR spectroscopy. Annu Rev Phys Chem 63: 1-24.

Hubbell WL, Altenbach C, Hubbell CM, Khorana HG (2003) Rhodopsin structure, dynamics, and activation: a perspective from crystallography, site-directed spin labeling, sulfhydryl reactivity, and disulfide cross-linking. Adv Protein Chem 63: 243-290. 
Huster D (2005) Investigations of the structure and dynamics of membrane-associated peptides by magic angle spinning NMR. Prog Nucl Magn Reson Spectrosc 46: 79-107.

Huster D (2014) Solid-state NMR spectroscopy to study protein-lipid interactions. Biochim Biophys Acta 1841: 1146-1160.

Huster D, Arnold K, Gawrisch K (1998) Influence of docosahexaenoic acid and cholesterol on lateral lipid organization in phospholipid membranes. Biochemistry 37: 17299-17308.

Huster D, Arnold K, Gawrisch K (2000) Strength of $\mathrm{Ca}^{2+}$ binding to retinal lipid membranes: consequences for lipid organization. Biophys J 78: 3011-3018.

Huster D, Xiao L, Hong M (2001) Solid-state NMR investigation of the dynamics of soluble and membrane-bound colicin la channel-forming domain. Biochemistry 40: 7662-7674.

Kim TH, Chung KY, Manglik A, Hansen AL, Dror RO, Mildorf TJ, Shaw DE, Kobilka BK, Prosser RS (2013) The role of ligands on the equilibria between functional states of a $G$ proteincoupled receptor. J Am Chem Soc 135: 9465-9474.

Kobilka B (2013) The structural basis of G-protein-coupled receptor signaling. Angew Chem Int Ed Engl 52: 6380-6388.

Kolodziejski W, Klinowski J (2002) Kinetics of cross-polarization in solid-state NMR: A guide for chemists. Chem Rev 102: 613-628.

Liang B, Arora A, Tamm LK (2010) Fast-time scale dynamics of outer membrane protein A by extended model-free analysis of NMR relaxation data. Biochim Biophys Acta 1798: 68-76.

Morcombe CR, Zilm KW (2003) Chemical shift referencing in MAS solid state NMR. J Magn Reson 162: 479-486.

Munowitz MG, Griffin RG, Bodenhausen G, Huang TH (1981) Two-dimensional rotational spin-echo nuclear magnetic resonance in solids: correlation of chemical shift and dipolar interactions. J Am Chem Soc 103: 2529-2533.

Nygaard R, Zou Y, Dror RO, Mildorf TJ, Arlow DH, Manglik A, Pan AC, Liu CW, Fung JJ, Bokoch MP, Thian FS, Kobilka TS, Shaw DE, Mueller L, Prosser RS, Kobilka BK (2013) The dynamic process of beta(2)-adrenergic receptor activation. Cell 152: 532-542.

Oates J, Faust B, Attrill H, Harding P, Orwick M, Watts A (2012) The role of cholesterol on the activity and stability of neurotensin receptor 1. Biochim Biophys Acta 1818: 2228-2233.

Opella SJ (1986) Protein dynamics by solid state nuclear magnetic resonance. Methods Enzymol 131: 327-361.

Palczewski K, Kumasaka T, Hori T, Behnke CA, Motoshima H, Fox BA, Le T, I, Teller DC, Okada T, Stenkamp RE, Yamamoto M, Miyano M (2000) Crystal structure of rhodopsin: A G protein-coupled receptor. Science 289: 739-745.

Palmer III AG, Williams J, McDermott A (1996) Nuclear magnetic resonance studies of biopolymer dynamics. J Phys Chem 100: 13293-13310.

Park SH, Casagrande F, Das BB, Albrecht L, Chu M, Opella SJ (2011) Local and global dynamics of the G protein-coupled receptor CXCR1. Biochemistry 50: 2371-2380. 
Park SH, Das BB, Casagrande F, Tian Y, Nothnagel HJ, Chu M, Kiefer H, Maier K, De Angelis AA, Marassi FM, Opella SJ (2012) Structure of the chemokine receptor CXCR1 in phospholipid bilayers. Nature 491: 779-783.

Pester O, Barrett PJ, Hornburg D, Hornburg P, Probstle R, Widmaier S, Kutzner C, Durrbaum M, Kapurniotu A, Sanders CR, Scharnagl C, Langosch D (2013) The backbone dynamics of the amyloid precursor protein transmembrane helix provides a rationale for the sequential cleavage mechanism of gamma-secretase. J Am Chem Soc 135: 1317-1329.

Prasanna X, Chattopadhyay A, Sengupta D (2014) Cholesterol modulates the dimer interface of the beta(2)-adrenergic receptor via cholesterol occupancy sites. Biophys J 106: 1290-1300.

Reichert D (2005) NMR studies of dynamic processes in organic solids. Ann Rep NMR Spectrosc 55: 159-203.

Reichert D, Zinkevich T, Saalwachter K, Krushelnitsky A (2012) The relation of the X-ray Bfactor to protein dynamics: insights from recent dynamic solid-state NMR data. J Biomol Struct Dyn 30: 617-627.

Rudolph R, Lilie H (1996) In vitro folding of inclusion body proteins. FASEB J 10: 49-56.

Scheidt HA, Meyer T, Nikolaus J, Baek DJ, Haralampiev I, Thomas L, Bittman R, Herrmann A, Müller P, Huster D. (2013) Cholesterol's Aliphatic Side Chain Structure Modulates Membrane Properties. Angew Chem Int Ed 52: 12848-12851.

Schmidt P, Berger C, Scheidt HA, Berndt S, Bunge A, Beck-Sickinger AG, Huster D (2010) A reconstitution protocol for the in vitro folded human $G$ protein-coupled $Y 2$ receptor into lipid environment. Biophys Chem 150: 29-36.

Schmidt P, Lindner D, Montag C, Berndt S, Beck-Sickinger AG, Rudolph R, Huster D (2009) Prokaryotic expression, in vitro folding, and molecular pharmacological characterization of the neuropeptide Y receptor type 2. Biotechnol Prog 25: 1732-1739.

Schmidt P, Thomas L, Müller P, Scheidt HA, Huster D (2014) The G protein-coupled neuropeptide $Y$ receptor type 2 is highly dynamic in lipid membranes as revealed by solidstate NMR spectroscopy. Chemistry 20: 4986-4992.

Schmidt-Rohr K and Spiess HW (1994) Multidimensional solid-state NMR and polymers. Academic Press, San Diego, 478 pp.

Son WS, Park SH, Nothnagel HJ, Lu GJ, Wang Y, Zhang H, Cook GA, Howell SC, Opella SJ (2012) 'q-Titration' of long-chain and short-chain lipids differentiates between structured and mobile residues of membrane proteins studied in bicelles by solution NMR spectroscopy. J Magn Reson 214: 111-118.

Soubias O, Gawrisch K (2012) The role of the lipid matrix for structure and function of the GPCR rhodopsin. Biochim Biophys Acta 1818: 234-240.

Soubias O, Niu SL, Mitchell DC, Gawrisch K (2008) Lipid-rhodopsin hydrophobic mismatch alters rhodopsin helical content. J Am Chem Soc 130: 12465-12471.

Soubias O, Teague WE, Gawrisch K (2006) Evidence for specificity in lipid-rhodopsin interactions. J Biol Chem 281: 33233-33241. 
Steyaert J, Kobilka BK (2011) Nanobody stabilization of G protein-coupled receptor conformational states. Curr Opin Struct Biol 21: 567-572.

Teague WE, Soubias O, Petrache H, Fuller N, Hines KG, Rand RP, Gawrisch K (2013) Elastic properties of polyunsaturated phosphatidylethanolamines influence rhodopsin function. Faraday Discuss 161: 383-395.

Venkatakrishnan AJ, Deupi X, Lebon G, Tate CG, Schertler GF, Babu MM (2013) Molecular signatures of G-protein-coupled receptors. Nature 494: 185-194.

Vogel A, Reuther G, Weise K, Triola G, Nikolaus J, Tan KT, Nowak C, Herrmann A, Waldmann H, Winter R, Huster D (2009) The lipid modifications of Ras that sense membrane environments and induce local enrichment. Angew Chem Int Ed 48: 8784-8787.

Warne T, Moukhametzianov R, Baker JG, Nehme R, Edwards PC, Leslie AG, Schertler GF, Tate CG (2011) The structural basis for agonist and partial agonist action on a beta(1)adrenergic receptor. Nature 469: 241-244.

Warne T, Serrano-Vega MJ, Baker JG, Moukhametzianov R, Edwards PC, Henderson R, Leslie AGW, Tate CG, Schertler GFX (2008) Structure of a beta(1)-adrenergic G-protein-coupled receptor. Nature 454: 486-491.

Wimley WC, White SH (1996) Experimentally determined hydrophobicity scale for proteins at membrane interfaces. Nat Struct Biol 3: 842-848.

Witte K, Kaiser A, Schmidt P, Splith V, Thomas L, Berndt S, Huster D, Beck-Sickinger AG (2013) Oxidative in vitro folding of a cysteine deficient variant of the $G$ protein-coupled neuropeptide $Y$ receptor type 2 improves stability at high concentration. Biol Chem 394: 1045-1056.

Yao Y, Ding Y, Tian Y, Opella SJ, Marassi FM (2013) Membrane protein structure determination: back to the membrane. Methods Mol Biol 1063: 145-158. 